Research Article

\title{
Hybrid Control for Bidirectional Z-Source Inverter for Locomotives
}

\author{
Vasanthi Vijayan $^{1}$ and S. Ashok ${ }^{2}$ \\ ${ }^{1}$ Department of Electrical \& Electronics Engineering, NSS College of Engineering, Palakkad, Kerala 678001, India \\ ${ }^{2}$ Department of Electrical Engineering, National Institute of Technology, Calicut, Kerala 673601, India
}

Correspondence should be addressed to Vasanthi Vijayan; vasanthivaishnav74@yahoo.com

Received 16 September 2014; Revised 9 December 2014; Accepted 27 December 2014

Academic Editor: Don Mahinda Vilathgamuwa

Copyright ( 2015 V. Vijayan and S. Ashok. This is an open access article distributed under the Creative Commons Attribution License, which permits unrestricted use, distribution, and reproduction in any medium, provided the original work is properly cited.

\begin{abstract}
Electric traction uses three phase locomotives in main line services. Three phase locomotives consist of voltage source inverters for driving the traction motors. This paper proposes a hybrid algorithm for bidirectional Z-source inverters in accelerating region of operation of locomotives. The speed control method adopted is same as that in the existing three phase locomotives which is variable voltage variable frequency. Bidirectional Z-source inverter is designed for getting the same output power as in voltage source inverter fed locomotives. Simulation is done in all regions of traction speed curve, namely, acceleration, free running, and braking by regeneration. The voltage stress across the devices and modulation index are considered while analyzing the proposed control algorithm. It is found that the modulation index remains at a high value over the entire range of frequencies. Due to the higher value of modulation index the harmonics in the inverter output voltage is reduced. Also the voltage stress across devices is limited to a value below the device rating used in the present three phase locomotives. A small scale prototype of the bi-directional $\mathrm{Z}$-source inverter fed drive is developed in the laboratory and the hybrid control was verified in the control topology.
\end{abstract}

\section{Introduction}

In the present scenario, three phase locomotives use voltage source inverters to drive the three phase traction motors. The disadvantages of voltage source inverters include impossibility of simultaneous turn on of devices in same leg, waveform distortion due to the dead time provided, vulnerability to electromagnetic interference (EMI) noise, and power conversion in the buck mode $[1,2]$. The solution to all these issues is $\mathrm{Z}$-source inverter which provides voltage boosting at the output with small change in the circuit configuration. Voltage boost is obtained by applying shoot through pulses to the inverter. The different control topologies of Z-source inverters, simple boost control and maximum boost control, are detailed out $[1,3]$. It has been reported that voltage stress across device in maximum boost control is less compared to simple boost control. Another method of control called constant boost control [4] minimizes the passive component requirements especially for low frequency or variable speed drive applications. Mathematical model of Z-source inverter was detailed out $[5,6]$. As the voltage source inverter, this can be applied to motor drives thereby providing good performance during voltage sags, improving power factor, and reducing line harmonics [7]. A high performance Zsource inverter obtained by providing a front end converter with dc filter enables the light load operation [8]. Z-source inverter has been applied to traction drive of fuel cell-battery hybrid vehicle and hence two-stage conversion is eliminated [9]. Power flow in two directions is possible by adding an extra switch to the Z-source inverter and the configuration is named as bidirectional Z-source inverter [10]. The design and closed loop control of high performance bidirectional Zsource inverter has been explained [11-15]. Detailed design and analysis of bidirectional Z-source inverter was presented [16]. It can operate in discontinuous conduction mode with small inductor and can be used in electric vehicles and renewable energy applications. Performance of bidirectional Z-source inverter fed hybrid electric vehicles is analyzed in motoring, regenerative braking, and grid interface operations with different types of control topologies [17]. Electric vehicle 
based on bi-directional Z-source inverter with nine switches has been reported [18]. Different control techniques of $\mathrm{Z}$ source inverter fed induction motors for electric vehicles have been compared [19]. Bidirectional Z-source inverter has been applied to fuel cell hybrid electric vehicle [9]. It has been used in hybrid electric vehicle to replace the two stage conversions and also in plug-in hybrid electric vehicle to increase efficiency by charging the battery directly from grid [20]. A control topology was explained for bidirectional Zsource inverter fed vehicle system [21].

Bidirectional Z-source inverter is applied to locomotives with variable voltage variable frequency method of speed control. Application of simple boost control or constant boost control alone in locomotives creates some issues. When simple boost control is used, device stress is more at higher frequency of operation. If constant boost control is used, a lower $\mathrm{dc}$ voltage is required for the inverter to operate in the lower frequency range of operation. Due to the above reasons, this paper proposes a hybrid algorithm for bidirectional Zsource inverter applied to locomotive applications. The boost factor and device stress is analyzed while developing the algorithm.

This paper is organized as follows. The description and design of bidirectional Z-source inverter for locomotive application is presented in Section 2. The proposed hybrid control topology is detailed out in Section 3. Simulation and experimental results are presented in Section 4. Conclusions are given in Section 5 .

\section{Description and Mathematical Equations of the System}

Figures 1 and 2 show the block diagram and power circuit diagram of bi-directional Z-source inverter fed locomotive respectively. It consists of traction transformer which steps down the single phase high voltage into lower value followed by active front end converter. There are even numbers of converters connected in $\mathrm{H}$ bridge to reduce the input current harmonics. The output voltage of converter is filtered and given as the input to the three phase bidirectional $\mathrm{Z}$-source inverter. The inverter drives a set of traction motors. The number of traction motors connected to the inverter is dependent on the power of locomotive. The number of inverters is decided by the number of $\mathrm{H}$ bridge converters.

The matrix equation of the induction motor in the stator reference frame [22] is given by

$$
\begin{aligned}
{\left[\begin{array}{c}
V_{\mathrm{qs}} \\
V_{\mathrm{ds}} \\
V_{\mathrm{qr}} \\
V_{\mathrm{dr}}
\end{array}\right]=} & {\left[\begin{array}{cccc}
R_{s}+p L_{s} & 0 & p L_{m} & 0 \\
0 & R_{s}+p L_{s} & 0 & p L_{m} \\
p L_{m} & -\omega_{r} L_{m} & R_{r}+p L_{r} & -\omega_{r} L_{r} \\
\omega_{r} L_{m} & p L_{m} & \omega_{r} L_{r} & R_{r}+p L_{r}
\end{array}\right] } \\
& \cdot\left[\begin{array}{c}
i_{\mathrm{qs}} \\
i_{\mathrm{ds}} \\
i_{\mathrm{qr}} \\
i_{\mathrm{dr}}
\end{array}\right], \\
& T_{e}=\frac{3 P}{4} L_{m}\left(i_{\mathrm{qs}} i_{\mathrm{dr}}-i_{\mathrm{ds}} i_{\mathrm{qr}}\right)
\end{aligned}
$$

where $p$ represents the differential operator $d / d t, R_{s}$ and $R_{r}$ are the stator resistances, $L_{s}, L_{r}$, and $L_{m}$ represent the stator, rotor, and magnetizing inductances, $V_{\mathrm{qs}}, V_{\mathrm{ds}}, V_{\mathrm{qr}}$, and $V_{\mathrm{dr}}$ are the quadrature and direct axes voltages of stator and rotor, respectively, $i_{\mathrm{qs}}, i_{\mathrm{ds}}, i_{\mathrm{qr}}$, and $i_{\mathrm{dr}}$ are the quadrature and direct axes currents of stator and rotor, respectively, and $\omega_{r}$ is the speed of the rotor in $\mathrm{rad} / \mathrm{s}$. The electromagnetic torque developed is given by (2), where $P$ is number of poles.

The matrix equation of $\mathrm{Z}$-source inverter is given in the following:

$$
\begin{aligned}
{\left[\begin{array}{l}
p i_{L} \\
p V_{c}
\end{array}\right]=} & {\left[\begin{array}{cc}
0 & \frac{2 d_{s}-1}{L} \\
\frac{1-2 d_{s}}{C} & 0
\end{array}\right]\left[\begin{array}{c}
i_{L} \\
v_{C}
\end{array}\right] } \\
+ & {\left[\begin{array}{cc}
\frac{1-2 d_{s}}{L} & 0 \\
0 & \frac{d_{s}-1}{L}
\end{array}\right]\left[\begin{array}{c}
V_{\mathrm{dc}} \\
i_{z}
\end{array}\right], }
\end{aligned}
$$

where $i_{L}$ and $v_{C}$ are the current though inductor and voltage across capacitor, respectively, $d_{s}$ is shoot through duty ratio, $L$ and $C$ are the inductance and capacitance of $Z$-source network respectively, $i_{z}$ is the output current of $Z$ network, and $V_{\mathrm{dc}}$ is the dc input voltage of the inverter. The inductance and capacitance are designed [11] by using

$$
\begin{gathered}
L_{1}=L_{2}=L=\frac{V_{\mathrm{dc}} T\left(2 V_{\mathrm{ph}}-V_{\mathrm{dc}}\right)}{2 k_{i} i_{P}\left(4 V_{\mathrm{ph}}-V_{\mathrm{dc}}\right)}, \\
C_{1}=C_{2}=C=\frac{i_{z} T\left(2 V_{\mathrm{ph}}-V_{\mathrm{dc}}\right)}{2 k_{v} V_{\mathrm{dc}}\left(4 V_{\mathrm{ph}}-V_{\mathrm{dc}}\right)},
\end{gathered}
$$

where $V_{\mathrm{ph}}$ is the peak phase ac voltage, $T$ is the switching period, $k_{i}$ and $k_{v}$ are the percentage ripple in the inductor current and capacitor voltage, respectively.

The equation for single phase system with source (input) inductance $L_{s}$ is

$$
V_{s}=p L_{s} i_{s}+V_{p}
$$

where $V_{s}$ and $i_{s}$ are the secondary voltage and current of transformer, $V_{p}$ is the voltage at the input terminals of front end converter, and $V_{p(\mathrm{pk})}, V_{s(\mathrm{pk})}$, and $I_{s(\mathrm{pk})}$ are the peak values. It is clear from (5) that the source inductance of the front end converter of the drive depends on the value of transformer voltage and input voltage of the converter. It is required that the power factor should be near to unity in both motoring and regenerative mode of operation of locomotives. The value of inductance is thus designed by considering phase angle between the transformer secondary voltage and current equal to zero.

\section{Proposed Hybrid Control Topology of the Locomotive}

The algorithm for proposed hybrid control is shown in Figure 3. The different regions of operation, namely, acceleration, free running, and braking by regeneration, are 


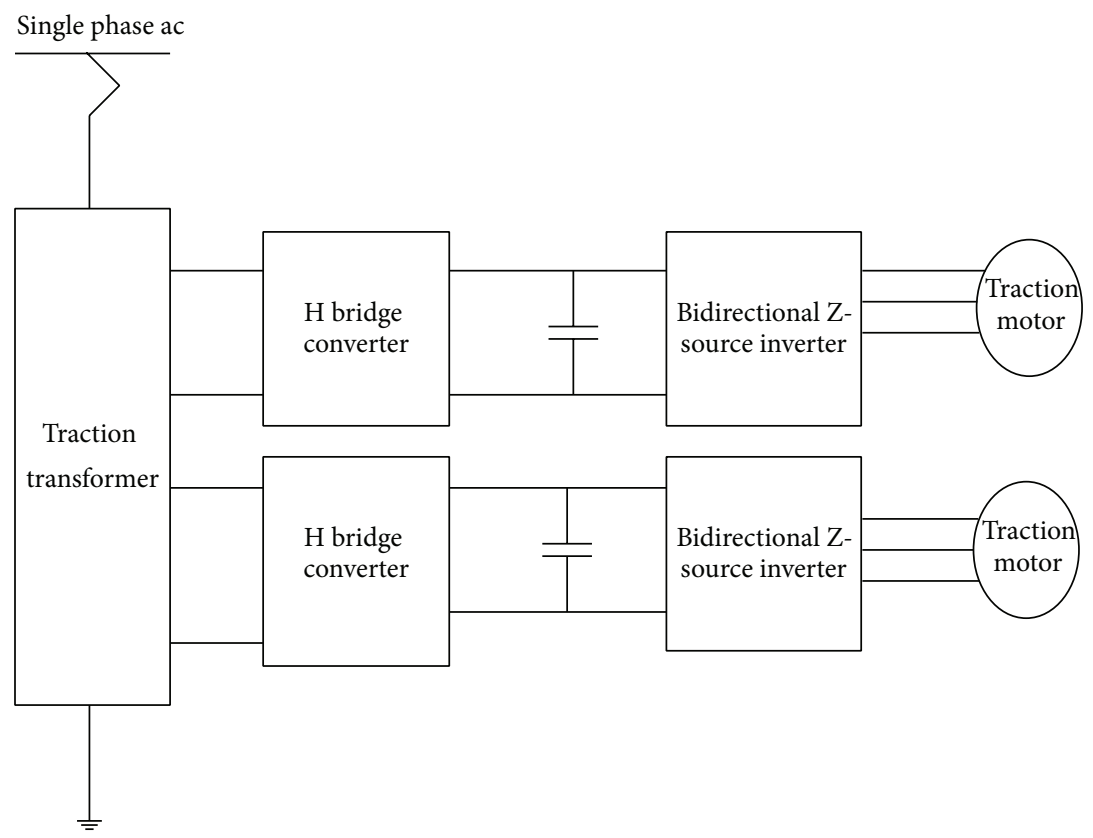

FIGURE 1: Block schematic of bidirectional Z-source inverter fed locomotive.

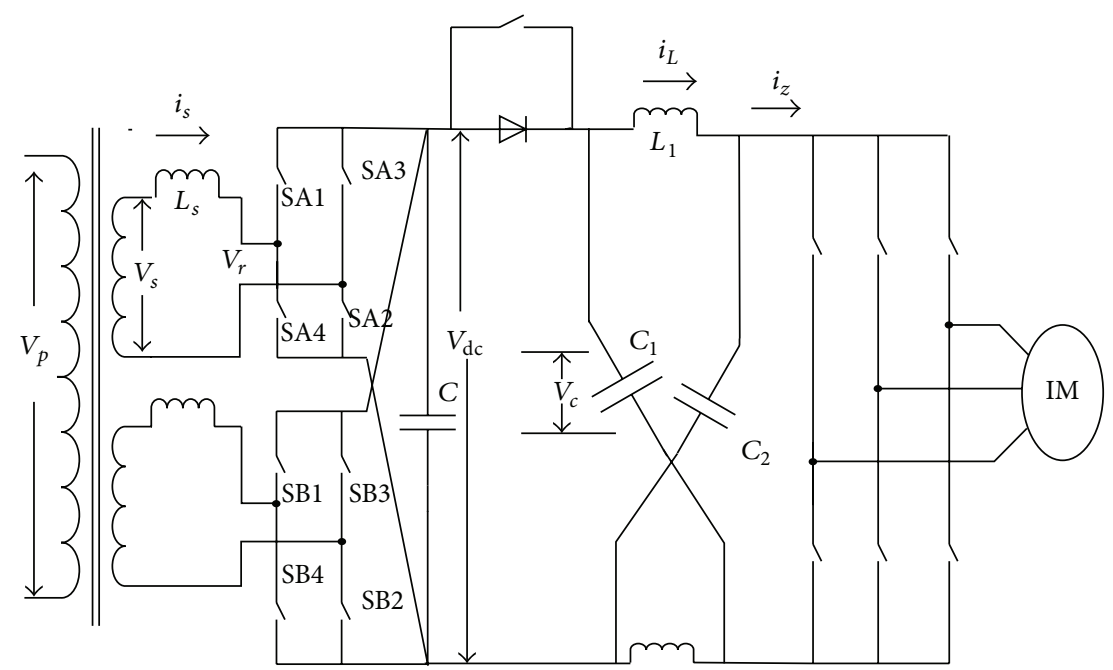

FIGURE 2: Power circuit of one set of bidirectional Z-source inverter fed locomotive drive.

controlled using different topologies. In all these regions the front end converter is controlled by sinusoidal pwm so as to get the power factor near to unity. The front end converter also keeps the output dc voltage at a constant value in all regions of operation of locomotive. In this work the dc voltage is kept constant at $1700 \mathrm{~V}$. In the existing system with voltage source inverter technology the dc link voltage used is $2800 \mathrm{~V}$. The capacitor bank rating has to be high which increases the cost.

The acceleration region of speed curve of the locomotive is controlled using variable voltage variable frequency. During this period the inverter output voltage is controlled by sine pwm. The acceleration up to the rated frequency of traction motor is obtained by three different methods of control. This is because $\mathrm{dc}$ input voltage of the inverter has to be kept constant in locomotive applications. Hence during the low frequency of operation the available dc voltage is enough to give the required motor voltage. The inverter works in the traditional voltage source inverter mode. During this period the dead time is not provided for the pulses. Dead time is the time required to avoid the bridge shoot through caused by the unsymmetrical turn on time and turn off time of the devices. It should be chosen as small as possible to ensure correct operation of voltage source inverter. There is no problem if shoot through occurs for the devices because of the presence of $\mathrm{Z}$-source network in the circuit. Shoot through time is the 


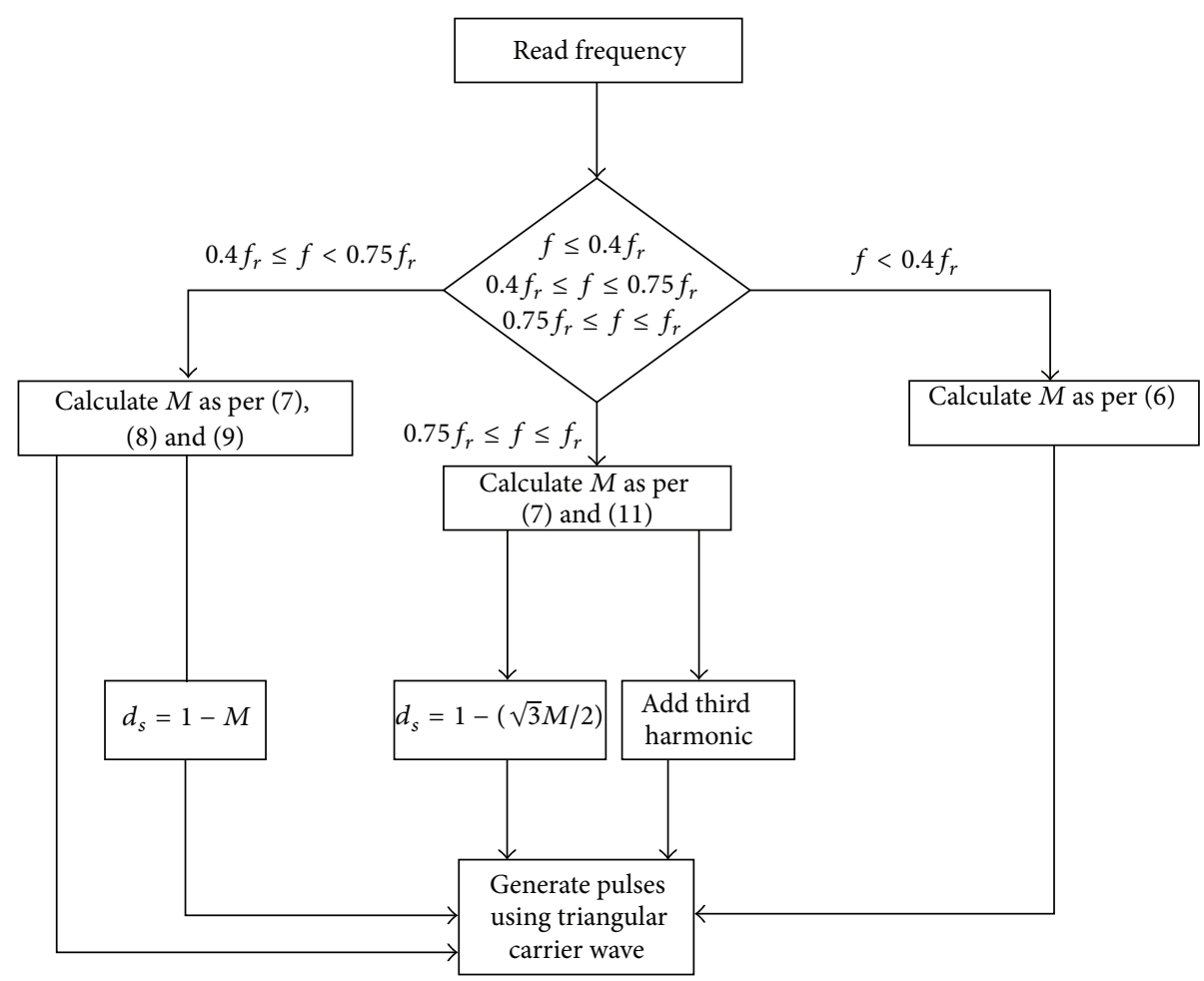

Figure 3: Proposed hybrid control.

time during which both devices in the same leg/two legs/three legs are turned on. In this work all the devices of the inverter are turned on during the shoot through time. By varying the shoot through time the output voltage of Z-source inverter can be varied.

The output voltage waveform distortion is less due to the absence of dead time. Due to the dead time the fundamental pole voltage of the inverter deviates from its sinusoidal nature; that is, the error voltage due to the dead time will get added to the fundamental pole voltage. But in the case of Z-source inverter, dead time is not required and is operated in voltage source mode with no dead time for frequencies up to $40 \%$ rated value. The modulation index of the inverter is calculated from the constant $\mathrm{v} / \mathrm{f}$ ratio and

$$
V_{L L 1}=\sqrt{\frac{3}{2}} \frac{M V_{\mathrm{dc}}}{2}
$$

With the increase in frequency of operation of traction motor, the control is changed to simple boost control [1] of bidirectional Z-source inverter. The shoot through pulses are applied to get the voltage boost at the output of inverter. The voltage gain, $G$, of the inverter during this period is calculated from (6) and

$$
V_{\mathrm{ph}}=\frac{G V_{\mathrm{dc}}}{2} .
$$

The modulation index $M$ and boost factor are obtained as per the following:

$$
\begin{gathered}
M=\frac{G}{2 G-1}, \\
B=\frac{G}{M} .
\end{gathered}
$$

The duty ratio $d_{s}$ for shoot through pulses is obtained from the boost factor by using

$$
B=\frac{1}{1-2 d_{s}} \text {. }
$$

The relations between $M$ and maximum value of shoot through duty ratio and voltage stress across $V_{\text {str }}$ device in simple boost control are given by

$$
\begin{gathered}
d_{s}=1-M, \\
V_{\mathrm{str}}=\frac{1}{2 M-1} V_{\mathrm{dc} .}
\end{gathered}
$$

Simple boost control can be applied for frequencies up to the rated value. But the voltage stress across the device at the rated frequency by this control is high. This work aims to apply bidirectional $\mathrm{Z}$-source inverter for locomotives without changing the device rating of the inverter bridge of existing locomotive. In order to use the same device, the stress has 
TABLE 1: Parameters used in simulation.

\begin{tabular}{lc}
\hline Rated voltage of motor $(\mathrm{V})$ & 2180 \\
Rated speed $(\mathrm{rpm})$ & 1585 \\
Rated current $(\mathrm{A})$ & 370 \\
Power factor & 0.86 \\
Z-source inductance $(\mathrm{mH})$ & 6 \\
Z-source capacitance $(\mu \mathrm{F})$ & 8500 \\
DC link voltage $(\mathrm{V})$ & 1700 \\
Rated frequency $(\mathrm{Hz})$ & 80 \\
\hline
\end{tabular}

to be limited to a maximum of $4500 \mathrm{~V}$. When frequency is about $75 \%$ rated value, the stress in simple boost control is greater than $4500 \mathrm{~V}$. Hence the control is changed to constant boost control with third harmonic injection which produces less stress.

In this control, [4] a third harmonic with magnitude of 1/6 of fundamental component is injected into the three phase voltage references to get the modulating wave. The shoot through pulses can be controlled by two straight lines as in simple boost control. The gain is calculated by using (6) and (7). The relation between modulation index and gain of the inverter is given by (11), while the shoot through duty ratio and voltage stress are obtained by (12) and (13). Consider

$$
\begin{gathered}
G=\frac{M}{\sqrt{3} M-1}, \\
d_{s}=1-\frac{\sqrt{3} M}{2}, \\
V_{s}=\frac{1}{\sqrt{3} M-1} V_{\mathrm{dc}} .
\end{gathered}
$$

Application of constant boost control with third harmonic injection to locomotives near the rated frequency produces less voltage stress across the devices. Also the modulation index for the rated frequency is higher in constant boost control than in simple boost control. This reduces the harmonics in the inverter output voltage at higher frequency of operation by variable voltage variable frequency control.

The proposed hybrid control is expressed in flowchart in Figure 2. Frequency of operation is read first by the digital signal processor. It is compared with the set value of rated frequency, $f_{r}$, to know whether it is less than $40 \%$ or between $40 \%$ and $75 \%$ or greater than $75 \%$ of rated value. If the operating frequency is less than $40 \%$ rated value, the control is directed to voltage source mode; that is, calculate the modulation index and generate the switching pulses. If the frequency is between $40 \%$ and $75 \%$ of rated value, simple boost control is applied by calculating $M$ and $d_{s}$ and then generating pulses.

If the frequency is greater than $75 \%$ of rated value, modulating wave is generated by adding $16 \%$ third harmonic to the fundamental component. The shoot through duty ratio is calculated and pulses are generated according to constant boost control principle.

\section{Simulation and Experimental Results}

Simulation of bidirectional Z-source inverter fed locomotive has been conducted with the parameters listed in Table 1. Analysis is made in the motoring (acceleration and free running) and regenerative braking mode of operation. In all regions of operation the front end controller keeps the input power factor near to unity and dc bus voltage constant. In this paper, the results were obtained by applying the proposed hybrid control for the inverter in the acceleration region of operation where variable voltage variable frequency is used.

4.1. Simulation Results. Since the dc bus voltage at the input of inverter remains constant, the value of modulation index for very low frequency in simple boost control is greater than unity. This indicates that there is no need for voltage boost for very low frequency region. Therefore shoot through pulses are not introduced and the inverter works in traditional voltage source mode with Z-source network in the circuit. The variation of modulation index with change in frequency is calculated as per (6) and (7). As frequency increases above $40 \%$, dc voltage is not enough to meet the motor requirements. Hence the control is changed to voltage boost mode with simple boost control for generating pulses. Shoot through pulses are introduced to get the voltage boost at the inverter output. The upper limit of voltage stress is limited to $4000 \mathrm{~V}$ so as to maintain the same device rating as in the existing locomotive. Hence the upper limit of frequency in simple boost control is limited to $75 \%$ of rated value. When the frequency reaches $75 \%$ of rated value, a third harmonic with magnitude $16 \%$ of fundamental component is added to the modulating wave. The control is changed to constant boost with third harmonic injection. The modulation index and shoot through duty ratio are calculated as per (11) and (12). The variation of modulation index and voltage stress across device according to frequency is tabulated in Table 2.

It is clear from Table 2 that, as frequency increases, modulation index increases, reducing harmonics in the inverter output voltage for the voltage source mode of operation. As frequency goes up modulation index decreases, while voltage stress increases in simple boost and constant boost control.

If the same control strategy was used for frequencies from $40 \%$ to rated value the modulation index would have been reduced to below 0.73 . This increases the harmonics at the inverter output voltage near to rated frequency. By adopting hybrid control, the least value of modulation index is 0.73 in the range $40 \%$ to rated frequency. Due to the reduction in harmonics overheating of stator windings can be reduced, thereby increasing the lifespan of motor. Voltage stress is also kept within $4500 \mathrm{~V}$. The comparison of modulation index, voltage stress in inverter output for frequencies in the high frequency region with simple boost control and constant boost control with third harmonic injection has also been given in Table 2. It is clear that the voltage stress is less than $4500 \mathrm{~V}$ as the frequency increases to rated frequency.

The speed of the motor with respect to time is plotted in Figure 4. The motor current and torque developed by the traction motor are plotted in Figure 5. For time $=0$ to $0.3 \mathrm{~s}$, 
TABLE 2: Variation of modulation index and voltage stress with frequency with proposed control topology.

\begin{tabular}{|c|c|c|c|c|c|c|c|c|c|c|c|}
\hline \multirow{3}{*}{$\begin{array}{l}\text { Control topology } \\
\text { Frequency }(\mathrm{Hz})\end{array}$} & \multirow{2}{*}{\multicolumn{2}{|c|}{$\begin{array}{l}\text { Low frequency region } \\
\text { Voltage source mode }\end{array}$}} & \multirow{2}{*}{\multicolumn{3}{|c|}{$\begin{array}{c}\text { Medium frequency region } \\
\text { Simple boost control }\end{array}$}} & \multicolumn{6}{|c|}{ High frequency region } \\
\hline & & & & & & \multicolumn{3}{|c|}{ Simple boost control } & \multicolumn{3}{|c|}{$\begin{array}{l}\text { Constant boot control with } \\
\text { third harmonic injection }\end{array}$} \\
\hline & 20 & 30 & 40 & 50 & 60 & 61 & 70 & 79 & 61 & 70 & 79 \\
\hline$M$ & $0.26 \quad 0.52$ & 0.79 & 0.96 & 0.81 & 0.73 & 0.73 & 0.69 & 0.66 & 0.8 & 0.84 & 0.91 \\
\hline Voltage stress (V) & \multicolumn{2}{|c|}{ Low, neglected } & 1860 & 2750 & 3640 & 3640 & 4530 & 5420 & 3001 & 3695 & 4460 \\
\hline
\end{tabular}

TABLE 3: Parameters for the prototype.

\begin{tabular}{lc}
\hline Parameters & Values \\
\hline Z-source parameters & $54 \mathrm{mH}, 5 \mu \mathrm{F}$ \\
DC voltage input (maximum) & $250 \mathrm{~V}$ \\
Motor ratings & $415 \mathrm{~V}, 50 \mathrm{~Hz}, 3$ phase, 0.6 A \\
\hline
\end{tabular}

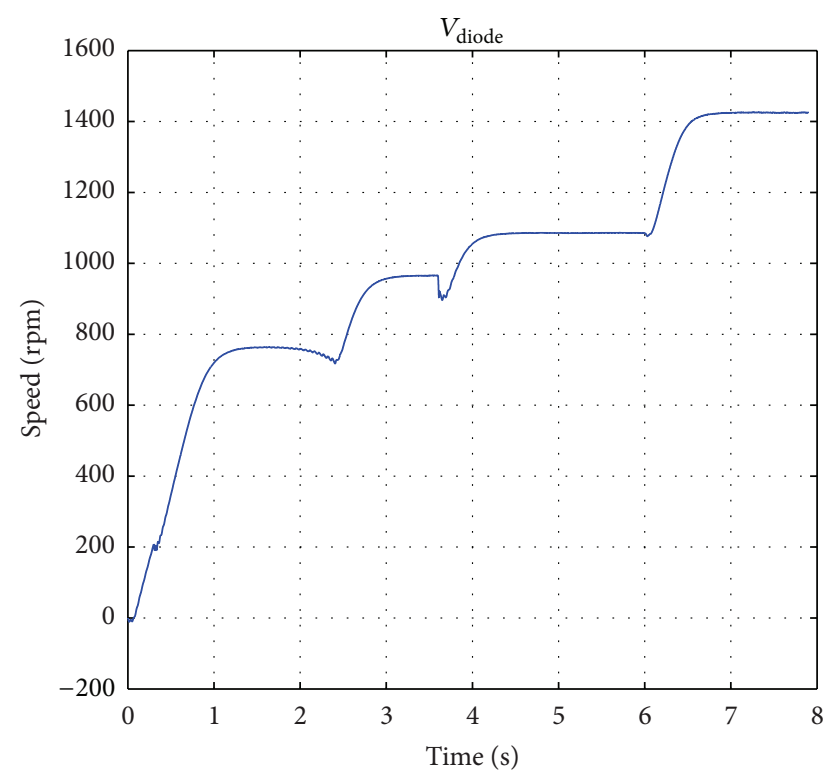

FIGURE 4: Speed of traction motor in all the three regions.

the inverter works as traditional voltage source inverter with the impedance source network in the circuit.

The inverter is operated as Z-source inverter for $t>0.3 \mathrm{~s}$. From $t=0.3 \mathrm{sec}$ to $3.7 \mathrm{sec}$, the control used is simple boost mode and for $t>3.7 \mathrm{~s}$, constant boost control with third harmonic injection is adopted.

4.2. Experimental Results. A scale down model has been developed with $0.5 \mathrm{hp}$ induction motor available in the laboratory to verify the proposed hybrid control strategy. The front end rectifier was a diode bridge and the dc bus voltage is kept constant. The pulses for each region of operation were generated using digital signal processor DSP TMSF2812. The switching frequency used in the prototype model is $5 \mathrm{kHz}$.
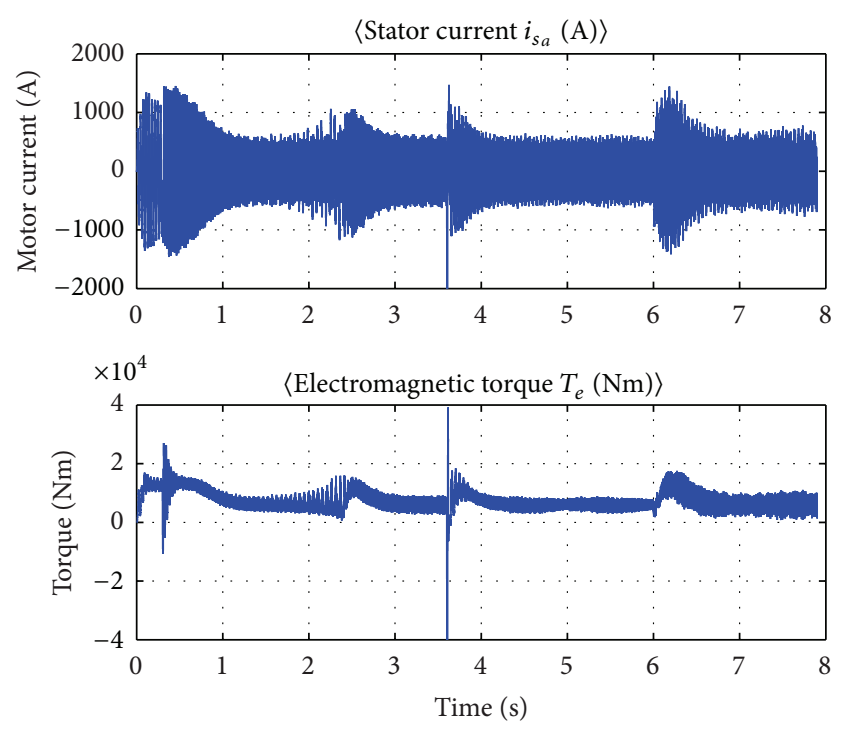

FIgURE 5: Motor current and torque in all the three regions.

The parameter used in the prototype model is given in Table 3 and setup for the laboratory model is shown in Figure 6.

As the rated frequency is $50 \mathrm{~Hz}$, the range for the three control modes has been selected as (1) low frequency range $(f<15 \mathrm{~Hz})$ for VSI mode with no dead time, (2) medium frequency range $(15 \leq f<20 \mathrm{~Hz})$ for simple boost control, and (3) higher frequency range ( $f \geq 20 \mathrm{~Hz}$ ) for constant boost control with third harmonic injection.

The filtered dc voltage from the output of diode rectifier was kept constant in all modes of operation. The inverter output voltages for the above three different control strategies (corresponding to typical frequencies $12 \mathrm{~Hz}, 18 \mathrm{~Hz}$, and $25 \mathrm{~Hz}$ ) for a typical dc voltage are shown in Figures 7, 9, and 11.

Experiment with different percentage of loading was conducted and typical current waveforms corresponding to load of approximately $50 \%$ rated value for different frequencies are shown in Figures 8, 10, and 12. Table 4 gives the variation of modulation index, line voltage at the inverter output, total harmonic distortion in the inverter output voltage, and speed of the motor in the three ranges of frequencies.

The current waveforms are shown for constant load in all the three control strategies; peak motor current is observed as $0.38 \mathrm{~A}$ which is approximately $50 \%$ of rated current. 
TABLE 4: Results obtained from the prototype (low and medium frequency operations).

\begin{tabular}{lcccccccc}
\hline & \multicolumn{3}{c}{ Low frequency range } & \multicolumn{3}{c}{ Medium frequency range } & \multicolumn{3}{c}{ High frequency range } \\
\hline$f(\mathrm{~Hz})$ & 10 & 12 & 14 & 15 & 17 & 19 & 20 & 23 \\
$V_{\mathrm{dc}}$ & 76 & 76 & 76 & 76 & 76 & 76 & 76 & 76 \\
$M$ & 0.73 & 0.81 & 0.9 & 0.94 & 0.86 & 0.81 & 0.90 & 0.84 \\
$V_{\text {rms }}$ & 38.7 & 41.3 & 48.6 & 63.1 & 72.1 & 88.3 & 93.5 & 107.3 \\
THDv & 93.5 & 85.9 & 80.6 & 76 & 81.4 & 88.2 & 97.7 & 90.6 \\
Speed $(\mathrm{rpm})$ & 240 & 290 & 344 & 389 & 453 & 518 & 563 & 625 \\
\hline
\end{tabular}

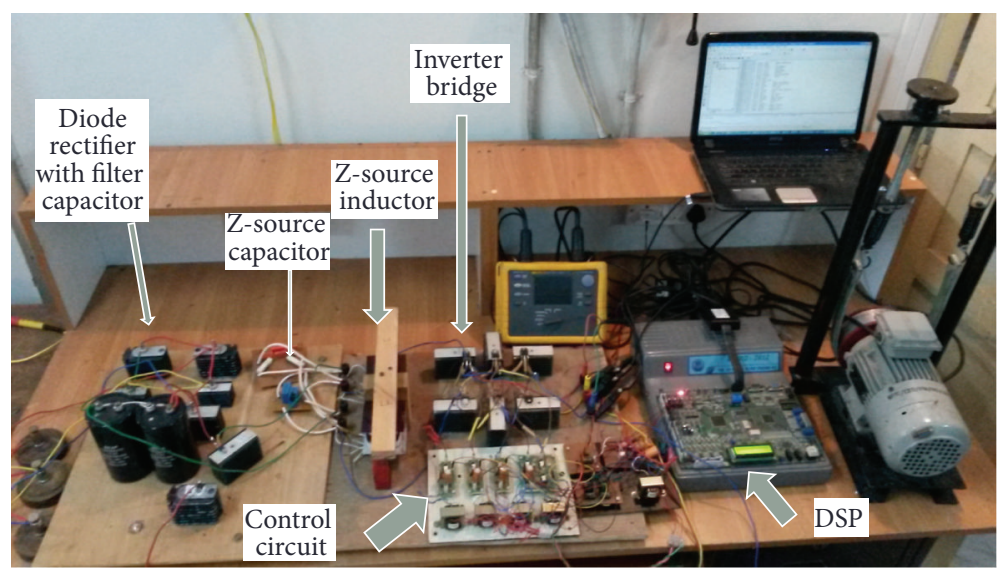

FIGURE 6: Prototype of Z-source inverter fed drive.

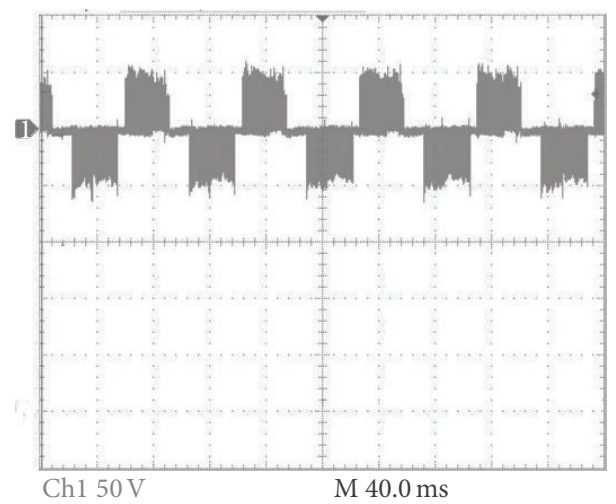

FIGURE 7: Inverter output voltage for low frequency $(12 \mathrm{~Hz})$ operation.

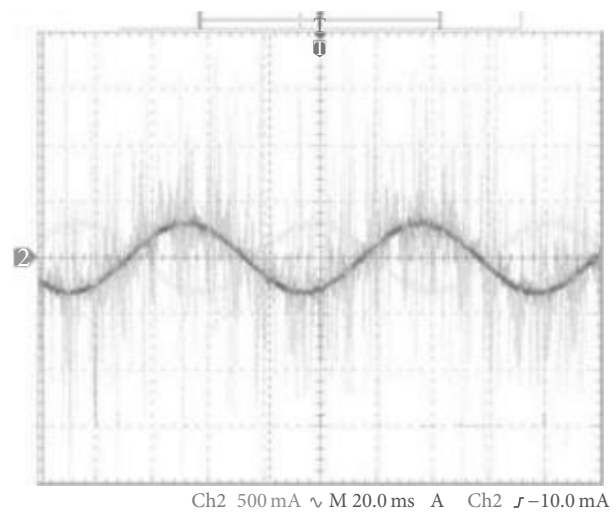

Figure 8: Motor current for low frequency $(f=12 \mathrm{~Hz})$ operation. 


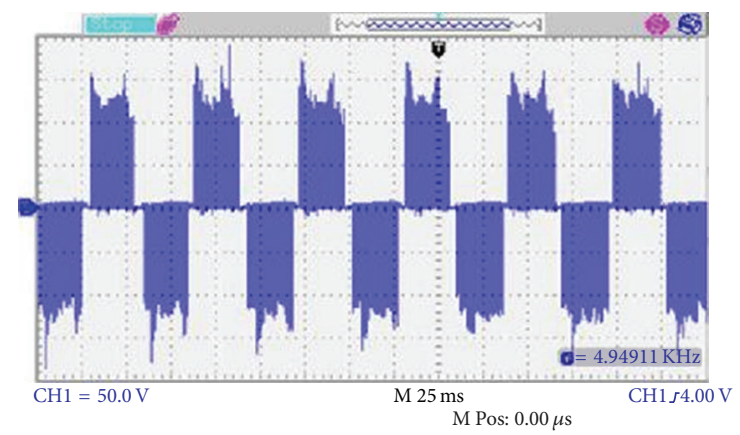

FIGURE 9: Inverter output voltage for medium frequency $(f=$ $18 \mathrm{~Hz}$ ) operation.

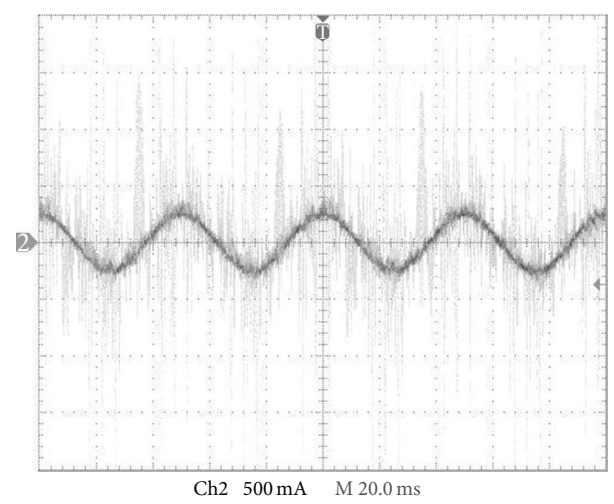

Figure 10: Motor current for medium frequency $(f=18 \mathrm{~Hz})$ operation.

\section{Conclusions}

This paper has proposed hybrid control for bidirectional Zsource inverter for locomotive applications. The analysis has been done in all regions of operations of locomotive. By applying bidirectional Z-source inverter, the dc link voltage can be reduced compared to the existing locomotive, thereby reducing the cost of capacitor bank. The control used in the acceleration region of operation of locomotive is variable voltage variable frequency. It has been found that the voltage stress is limited to a value below the device rating in existing locomotive. The modulation index is high during the entire acceleration period which results in reduction of inverter output voltage harmonics. A laboratory model has been implemented and low, medium and high frequency ranges of operation have been verified.

\section{Conflict of Interests}

The authors declare that there is no conflict of interests regarding the publication of this paper.

\section{Acknowledgment}

The authors express their gratitude to Indian Railways for the permission for data collection and measurement.

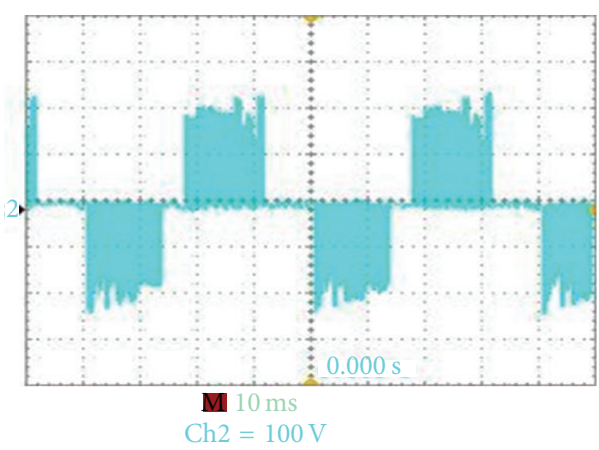

FIGURE 11: Inverter output voltage for high frequency $(f=25 \mathrm{~Hz})$ operation.

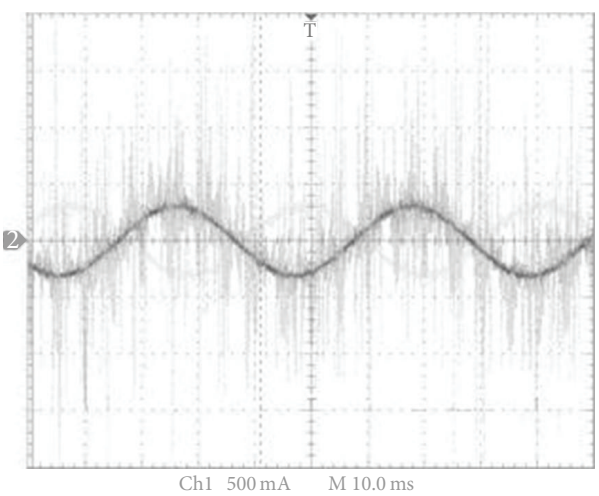

FigURE 12: Motor current for high frequency $(f=25 \mathrm{~Hz})$ operation.

\section{References}

[1] F. Z. Peng, "Z-source inverter," IEEE Transactions on Industry Applications, vol. 39, no. 2, pp. 504-510, 2003.

[2] M. Shen, A. Joseph, J. Wang, F. Z. Peng, and D. J. Adams, "Comparison of traditional inverters and Z-source inverter for fuel cell vehicles," IEEE Transactions on Power Electronics, vol. 22, no. 4, pp. 1453-1463, 2007.

[3] M. Shen, J. Wang, A. Joseph, F. Z. Peng, L. M. Tolbert, and D. J. Adams, "Maximum constant boost control of the Zsource inverter," in Proceedings of the IEEE Industry Applications Conference, October 2004.

[4] M. Shen, J. Wang, A. Joseph, F. Z. Peng, L. M. Tolbert, and D. J. Adams, "Constant boost control of the Z-source inverter to minimize current ripple and voltage stress," IEEE Transactions on Industry Applications, vol. 42, no. 3, pp. 770-778, 2006.

[5] M. Shen, Q. Tang, and F. Z. Peng, "Modeling and controller design of the Z-source inverter with inductive load," in Proceedings of the IEEE Power Electronics Specialists Conference (PESC '07), pp. 1804-1809, June 2007.

[6] P. C. Loh, D. M. Vilathgamuwa, C. J. Gajanayake, Y. R. Lim, and C. W. Teo, "Transient modeling and analysis of pulse-width modulated Z-source inverter," IEEE Transactions on Power Electronics, vol. 22, no. 2, pp. 498-507, 2007.

[7] F. Z. Peng, A. Joseph, J. Wang et al., "Z-source inverter for motor drives," IEEE Transactions on Power Electronics, vol. 20, no. 4, pp. 857-863, 2005. 
[8] X. Ding, Z. Qian, S. Yang, B. Cui, and F. Peng, "A new adjustablespeed drives (ASD) system based on high-performance Zsource inverter," in Proceedings of the IEEE Conference on Industry Applications, pp. 2327-2332, September 2007.

[9] F. Z. Peng, M. Shen, and K. Holland, "Application of Z-source inverter for traction drive of fuel cell-battery hybrid electric vehicles," IEEE Transactions on Power Electronics, vol. 22, no. 3, pp. 1054-1061, 2007.

[10] M. Yamanaka and H. Koizumi, "A bi-directional Z-source inverter for electric vehicles," in Proceedings of the International Conference on Power Electronics and Drive Systems (PEDS '09), pp. 574-578, November 2009.

[11] S. Rajakaruna and B. Zhang, "Design and control of a bidirectional Z-source inverter," in Proceedings of the 19th Australasian Universities Power Engineering Conference (AUPEC '09), pp. 1-6, September 2009.

[12] O. Ellabban, J. Van Mierlo, and P. Lataire, "A new closed loop speed control of induction motor fed by a high performance Zsource inverter," in Proceedings of the IEEE Electrical Power \& Energy Conference, pp. 1-6, 2010.

[13] X. Ding, Z. Qian, S. Yang, and F. Peng, "A new feedforward compensation to reject DC-link voltage ripple in bi-directional Z-source inverter ASD system," in Proceedings of the 23rd Annual IEEE Applied Power Electronics Conference and Exposition (APEC '08), pp. 1809-1813, IEEE, Austin, Tex, USA, February 2008.

[14] J. Rabkowski, R. Barlik, and M. Nowak, "Pulse width modulation methods for bidireetional/high-performance Z-souree inverter," in Proceedings of the 39th IEEE Annual Power Electronics Specialists Conference (PESC '08), pp. 2750-2756, Rhodes, Greece, June 2008.

[15] Y. Tang, S. Xie, and J. Ding, "Pulsewidth modulation of Zsource inverters with minimum inductor current ripple," IEEE Transactions on Industrial Electronics, vol. 61, no. 1, pp. 98-106, 2014.

[16] H. Xu, F. Z. Peng, L. Chen, and X. Wen, "Analysis and design of Bi-directional Z-source inverter for electrical vehicles," in Proceedings of the 23rd Annual Applied Power Electronics Conference and Exposition (APEC '08), pp. 1252-1257, Austin, Tex, USA, 2008.

[17] O. Ellabban, J. Van Mierlo, and P. Lataire, "Control of a bidirectional Z-Source Inverter for hybrid electric vehicles in motoring, regenerative braking and grid interface operations," in Proceedings of the IEEE Electrical Power and Energy Conference, pp. 1-6, 2010.

[18] S. M. Dehghan, M. Mohamadian, and A. Yazdian, "Hybrid electric vehicle based on Bi-directional $\mathrm{Z}$-source nine-switch inverter," IEEE Transactions on Vehicular Technology, vol. 59, no. 6, pp. 2641-2653, 2010.

[19] O. Ellabban, J. Van Mierlo, and P. Lataire, "A comparative study of different control techniques for an induction motor fed by a Z-source inverter for electric vehicles," in Proceedings of the 3rd IEEE International Conference on Power Engineering, Energy and Electrical Drives, Torremolinos, Spain, May 2011.

[20] O. Ellabban, J. van Mierlo, P. Lataire, and P. van Den Bossche, "Z-source inverter for vehicular applications," in Proceedings of the 7th IEEE Vehicle Power and Propulsion Conference, VPPC 2011, pp. 1-6, September 2011.

[21] Z. Luan and D. Xu, "The control strategy of bidirectional Z-source inverter for vehicle system," in Proceedings of the IEEE 7th International Power Electronics and Motion Control
Conference (IPEMC '12), pp. 1971-1975, Harbin, China, June 2012.

[22] R. Krishnan, Electric Motor Drives: Modelling, Analysis and Control, India Pearson Education, 2003. 

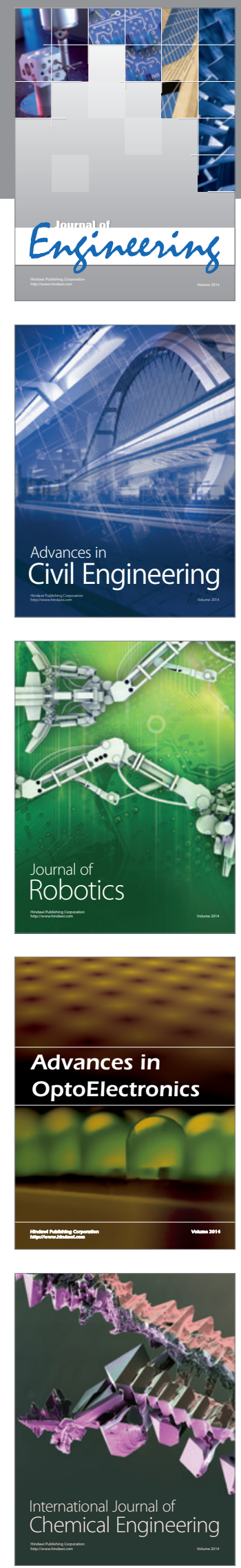

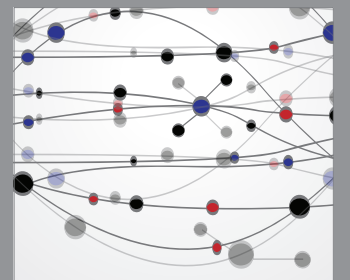

The Scientific World Journal
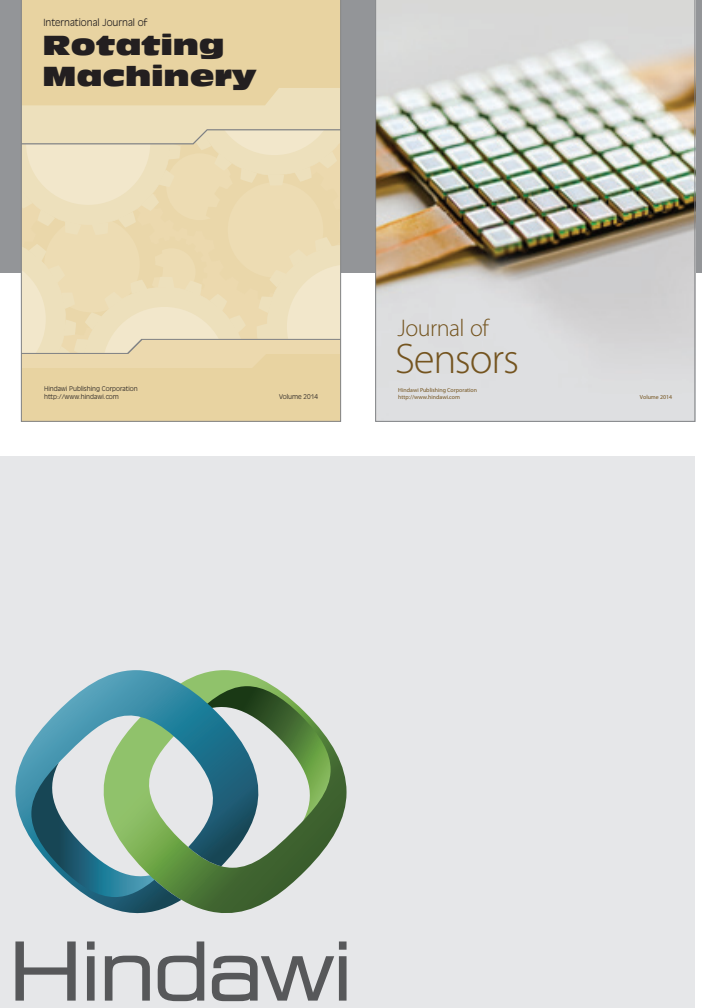

Submit your manuscripts at http://www.hindawi.com
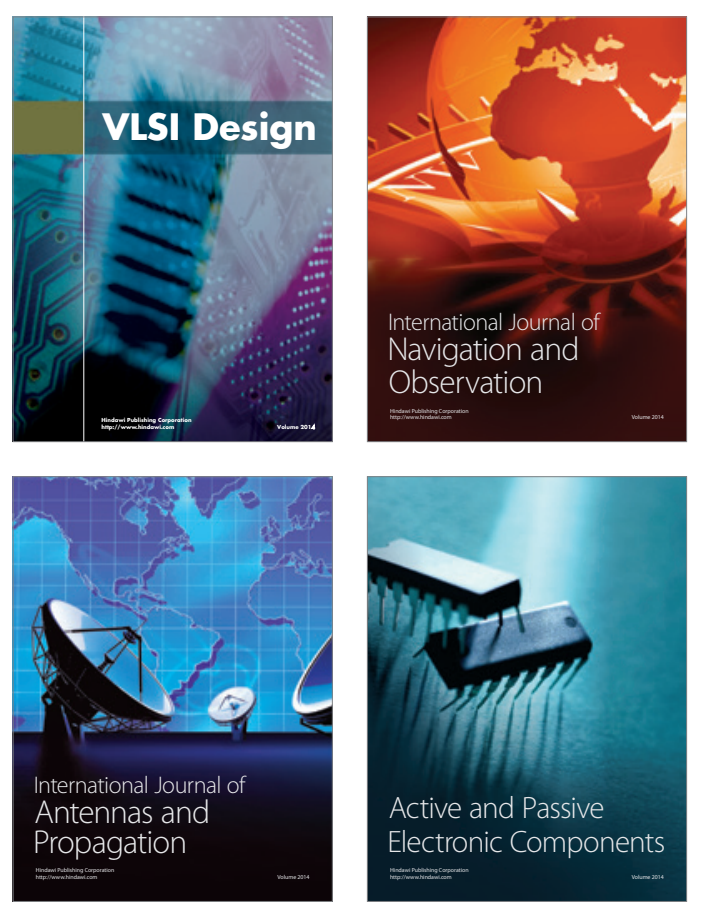
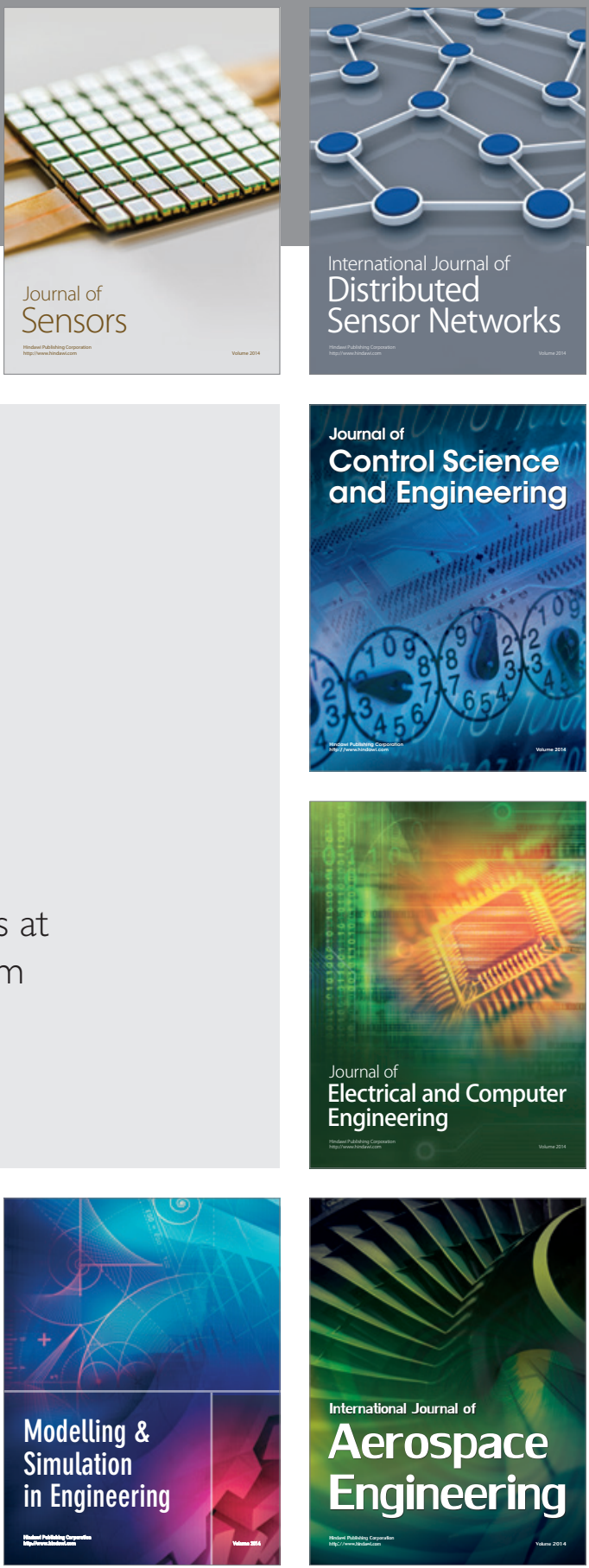

Journal of

Control Science

and Engineering
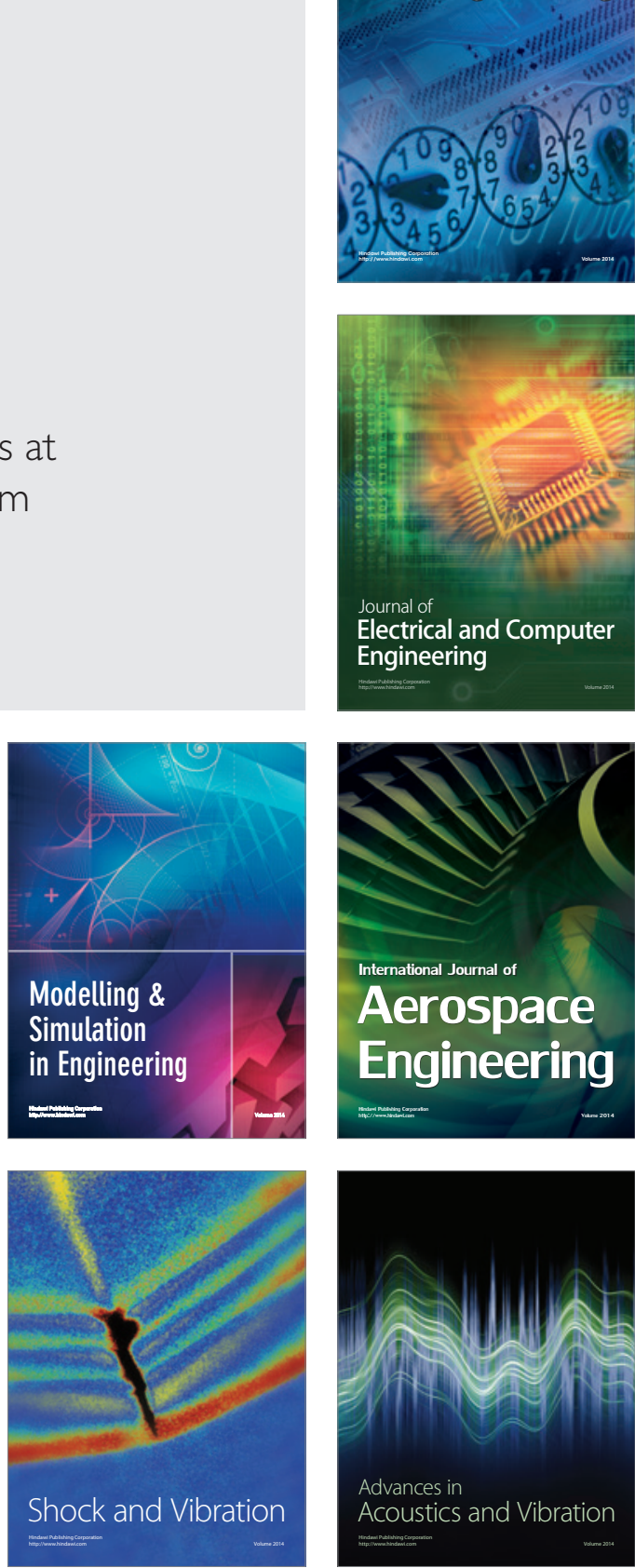